\title{
Adsorption and Decomposition of Chemical Warfare Agents by Metal-Organic Framework
}

\author{
Ozan Yağmuroğlu* \\ CBRN (Chemical, Biological, Radiological, Nuclear) Defense Department, Ministry of National Defense, Turkey \\ *Corresponding author: Ozan Yağmuroğlu, CBRN (Chemical, Biological, Radiological, Nuclear) Defense Department, \\ Ministry of National Defense, Turkey
}

\begin{tabular}{|c|c|}
\hline ARTICLE INFO & ABSTRACT \\
\hline $\begin{array}{l}\text { Received: 慧 February 20, } 2020 \\
\text { Published: 慧 February 28, } 2020\end{array}$ & $\begin{array}{l}\text { With the discovery of chemical weapons, mankind has faced a great threat. The fact } \\
\text { that these weapons caused mass human deaths and were relatively easy to develop made } \\
\text { the countries obliged to take precautions in this regard. During World War I, nearly } 2\end{array}$ \\
\hline $\begin{array}{l}\text { Citation: Ozan Yağmuroğlu. Adsorption } \\
\text { and Decomposition of Chemical Warfare } \\
\text { Agents by Metal-Organic Framework. } \\
\text { Biomed J Sci \& Tech Res 26(1)-2020. BJSTR. } \\
\text { MS.ID.004306. }\end{array}$ & $\begin{array}{l}\text { chemical weapons before World War II began. Thus, the threat of chemical weapons } \\
\text { on humanity has reached a much more critical point. Especially the development of } \\
\text { chemical weapons and the production of nervous agents increased during World War II } \\
\text { and during the cold war. Chemical weapons developed by the countries started to fall into } \\
\text { the hands of terrorist groups. Sarin gas was used in the terrorist attack that took place } \\
\text { in Matsumoto, Japan in 1994. This incident went down in history as the first terrorist } \\
\text { attack in which sarin gas was used. These events show how critical it is to take action } \\
\text { against chemical warfare agents. The first method of protection from the toxic effects } \\
\text { of chemical warfare agents is to destroy the toxic effects by breaking down chemical } \\
\text { warfare agents. In this study, the metal organic frames used for this purpose in recent } \\
\text { years will be mentioned. }\end{array}$ \\
\hline
\end{tabular}

\section{Introduction}

As a result of their toxic effects; chemical substances that have properties such as killing, injuring or disabling basic life functions are generally called chemical warfare agents. The Chemical Weapons Convention, signed in 1993, defined the devices and ammunition required to spread chemical warfare agents, and any specially designed equipment for their use, as chemical weapons. These weapons are; in addition to killing people, used for purposes such as making food stocks unusable with contamination, rendering high economic value targets inoperable, making military and civilian personnel use protective clothing and tools, reducing their mobility and referring military units to undesirable directions [1]. The situation that occurs with the use of chemical weapons against enemy countries in the field of war is called chemical warfare. The earliest examples of chemical warfare took place on the stone age $(10,000$ B.C). The warriors living in South Africa in those years produced poisonous arrows using the poisons they obtained from scorpions, snakes and plants. In 2000 B.C., soldiers in India made a fire on the battlefield and used the fumes as a weapon against their enemies. When the Chinese inscriptions from the 7th century
B.C. are examined, it is seen that the plants that emit smoke are listed and how to use them. In 600 B.C., the Assyrians excelled by contaminating their enemies' water sources with poisonous mushrooms. The Spartans placed a mixture of coal, sulfur and pitch in a wooden barrel and burned it and sent the fumes to the enemy defense lines with the blowers. In the $4^{\text {th }}$ century B.C., the Chinese burned mustard and other poisonous plants in large pits and neutralized their enemies with the poisonous smoke coming out of it. Chemical agents in the modern sense were used for the first time in the First World War. For this reason, the First World War is called "The War of the Chemists". Chlorine gas, which has an unpleasant smell and greenish yellow color, is the first chemical agent used in World War I. With the end of the First World War, many countries tried to ban chemical warfare by preventing the production and use of chemical warfare agents.

For this purpose, the Geneva protocol was signed in 1925 with the approval of 16 countries. The Geneva protocol is committed to not using chemical weapons in war. However, there is no article in the protocol that prohibits the production, transfer or storage of 
chemical weapons. Until the mid-1930s, phosgene and mustard were considered the most dangerous chemical warfare agents. This situation ended with the discovery of nerve agents. When trying to develop insecticide in the laboratory, tabun gas was isolated by chance. Then, tests were carried out on experimental animals using tabun gas. As a result of the studies, it was determined that the experimental animals died approximately 20 minutes after exposure to tabun gas [2]. Different criteria can be considered when classifying chemical warfare agents. Considering their mechanism of action and usage patterns, the most important criteria are physical state, toxicological feature and volatility. The classification of chemical warfare agents according to their toxicological properties is as follows; nerve agents, choking agents, blood poisoning agents, blister agents and non-lethal chemical agents.

The discovery of nerve agents is based on studies to develop more effective pesticides. Pesticides are chemicals used to destroy pests and microorganisms that damage the plant [3-5]. Molecular structures of both insecticides and nerve agents are based on organophosphorus compounds [5]. Organophosphorus compounds show their effects in the body by blocking nerve conduction. These compounds are generally esters, amides and derivatives of phosphoric acid in their structure. Organophosphates have lipid solubility [6]. Therefore, they are taken into the body by the skin, mucosa, conjunctiv and respiratory tract. They are also used as a chemical agent or drug in animal and human medicine as a chemical warfare agent in nervous system studies and military purposes [7]. This group of chemicals is most commonly used in pesticides, insecticides, acaricides, etc. They are used commercially and can be easily obtained commercially $[4,8]$.

The general chemical structures of organophosphorus compounds are as follows; The center of the molecule has a phosphate atom and the phosphate atom can double bond with oxygen or sulfur. R1-R2 in the general chemical structure represents hydrogen, alkyl (including cyclic structure), aryl, alkoxy, alkylthiole and amino groups $[3,9]$. X represents halogens, cyano and thiol groups and inorganic-organic acids. The general chemical structure of organophosphorus compounds is as shown in Figure
1 of organophosphorus compounds. The organophosphorous compounds show their effect on the body through the inhibition of the enzyme acetylcholine esterase. OPCs are hydrolyzed by the enzyme by binding to the serine amino acid present in the active site of the AChE (Acetylcholinesterase) enzyme. Thus, the active site of the enzyme is phosphorylated [10]. The reaction between the AChE enzyme and the OPCs takes place in two steps. First, a reversible enzyme-inhibitor complex is formed.

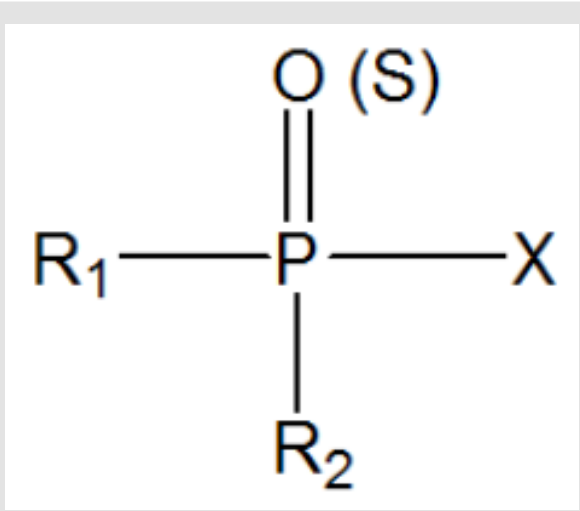

Figure 1: General chemical structure of organophosphorus compounds.

The rate of formation of this complex depends on the structure of the organophosphorous compound, the molecular size and the alkyl groups. After formation of the recycle complex, the substitution of the alkyl group in the structure with -OH results in a non-irreversible complex. This event is called aging and shown in Figure 2 [11-13]. One of the most commonly used methods for neutralizing nerve agents is the removal of the R-X bond [14,15]. Organophosphorus compounds can be directly hydrolyzed with water. However, this process is slow and takes a long time [16]. In order for the nerve agents to decomposition effectively, they must first be held by the adsorbing materials developed. Metal organic frames perform perfectly for adsorption of nerve agents and toxic chemicals thanks to their porous structure [17]. The metal organic frame is a new type of material with a porous structure, a high surface area, and inorganic cores connected by organic networks [18].

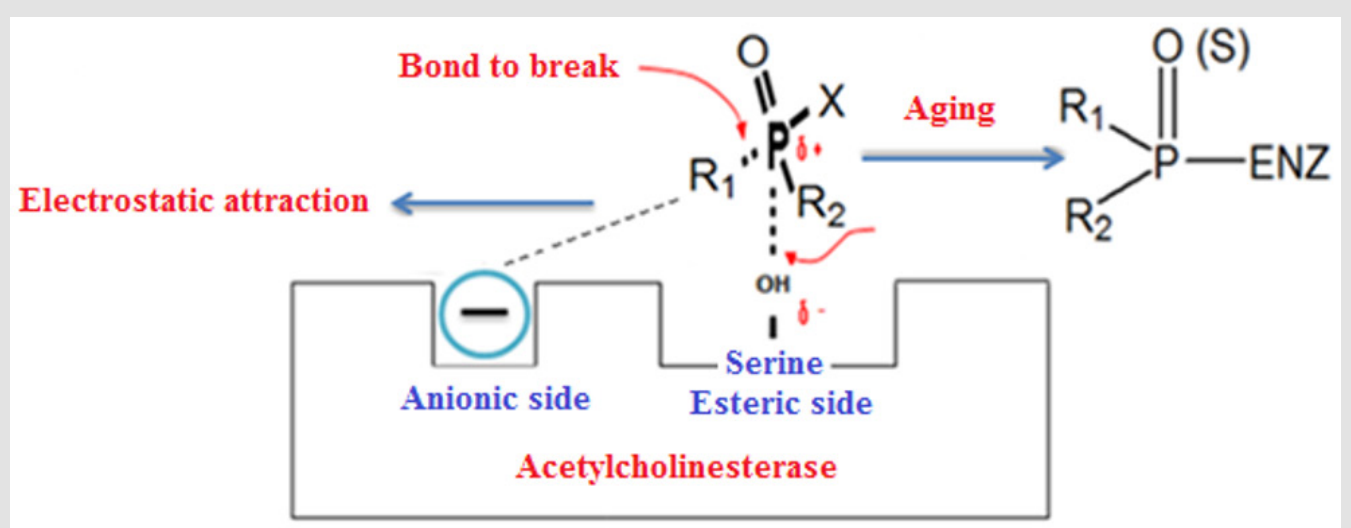

Figure 2: Reaction between organophosphorus compounds and AChE. 
Thanks to these features, they have the potential to be used in place of the currently used adsorbents. They are used commercially for gas storage, gas separation and catalytic decontamination of nerve agents [19-22]. Katz et al. have developed a metal organic framework-based material to break down nerve agent simulants. In their studies, they used 4-nitrophenyl phosphate (DMNP) as a nerve agent simulant. DMNP has been preferred because it has similar properties to G-series nerve agents. They used UiO-66 (12-connected Zr6-based MOF) as the metal organic framework. The UiO-66 rapidly catalyzes the breakdown of nerve agent simulants. The developed metal organic framework can hydrolyze dimethyl 4-nitrophenyl phosphate (DMNP) by $1 / 2$ in 50 minutes at room temperature [23]. Zhao et al. developed nanofibers with metal organic framework for the breakdown of chemical warfare agents. The main reason for using nanofiber in the study is that nanofibers have high surface area, mechanical strength and water vapor carrying properties.

Nerve agent simulant was not used in this study. Instead, it was studied with soman, a real nervous agent. The developed MOF-nanofiber material breaks down the nerve agent soman in a short period of 2-3 minutes [24]. Kim et al. modified a cotton fabric for breaking up chemical warfare agents. For this purpose, the fabric surface was first treated with an alkaline solution. Thus, the number of hydroxyl groups on the fabric surface has been increased. Then, the cotton fabric surface was functionalized with a metal organic frame (UiO-66-NH2). As a result of the analysis of the fabric surface with instrumental devices, it was seen that the surface was homogeneously covered with Ui0-66- $\mathrm{NH}_{2}$. Soman and sulfur mustard were used to test the chemical warfare agent disintegration ability of the fabric functionalized using a metal organic frame. The test results have shown that the developed cotton fabric has an excellent performance in breaking down chemical warfare agents [25].

\section{References}

1. Yağmuroğlu O (2018) Chemical defense and security. Eskişehir 3: 30.

2. Yağmuroğlu O, Diltemiz SE (2020) Development of QCM based biosensor for the selective and sensitive detection of paraoxon. Analytical Biochemistry 591: 113572.

3. Marrs TC, Balantyne B (2002) Pesticide toxicology. Wiley, New York, USA.

4. Sunay S (2010) Investigation of paraoxonase polymorphism and paraoxonase enzyme activity in individuals exposed to pesticides. Doctoral Thesis, Ankara University, Ankara.

5. Yağmuroğlu O (2017) Development of paraoxon-based sensors for the detection of chemical warfare agents. Doctoral Thesis. Anadolu University, Eskişehir, Turkey.
6. Jeyeratnam J (1990) Pesticides: poisining as a global health problem. World Health Stat, pp. 139-144.

7. Kamanyire R, Karalliedde L (2004) Organophosphate toxicity and occupational exposure. Occup Med Lond, 54(2): 69-75.

8. Hıncal F, Çeliker A, Özgüven Ş, Kaya E (1991) The effects of chemical and biological warfare agents on health. Ankara.

9. Karayılanoğlu T (2003) Medical defense and pesticides in chemical attack. Ankara.

10. Şanlı, Y (1984) Environmental problems and food contamination. Selçuk University Journal of Veterinary Faculty Special Issue: 17-37.

11. Güler Ç, Uz H, Sur H (1998) Pesticides. Standard Economic and Technical Journal 440(37): 54-59.

12. Gürcan T (2001) Pesticide residues and their importance. World Food Magazine May Issue: 67-72.

13. Diltemiz S, Yağmuroğlu O (2019) Development of reflectometric interference spectroscopy-based sensors for paraoxon determination. J Sci Technology C Life Sci Biotech 8 (1): 12-22.

14. G Lunn, E Sansone (1994) Safe disposal of diisopropyl fluorophosphate (DFP). Appl Biochem Biotechnol 49: 165-172.

15. MK Kinnan, WR Creasy, LB Fullmer, HL Schreuder Gibson, M Nyman (2014) Nerve Agent Degradation with Polyoxoniobates. Eur J Inorg Chem 14: 2361- 2367.

16. Moon SY, Liu Y, Hupp JT, Farha OK (2015) Instantaneous hydrolysis of nerve-agent simulants with a six-connected zirconium-based metalorganic framework. Angewandte Chemie International Edition 54(23): 6795-6799.

17. Decoste JB, Peterson GW (2014) Metal-organic frameworks for air purification of toxic chemicals. Chemical Reviews 114(11): 5695-5727.

18. Zhou HC, Long JR, Yaghi OM (2012) Introduction to metal-organic frameworks. Chemical Reviews 112(2): 673-674.

19. Getman RB, Bae YS, Wilmer CE, Snurr RQ (2012) Review and analysis of molecular simulations of methane, hydrogen and acetylene storage in metal-organic frameworks. Chemical Reviews 112(2): 703-723.

20. Huang Y, Ke SH (2013) Hydrogen storage in metal-organic frameworks. Chem Rev 112(2): 782-835.

21. Sumida K, Herm ZR, McDonald T, Bloch ED, Mason J, et al. (2011) Carbon dioxide capture in metal-organic frameworks. ACS National Meeting Book of Abstracts 112(2): 724-781.

22. Plonka AM, Chen X, Wang H, Krishna R, Dong X, et al. (2016) Light Hydrocarbon Adsorption Mechanisms in Two Calcium-Based Microporous Metal Organic Frameworks. Chemistry of Materials 28(6): 1636-1646.

23. Katz MJ, Mondloch JE, Totten RK, Park JK, Nguyen ST, et al. (2013) Simple and compelling biomimetic metal-organic framework catalyst for the degradation of nerve agent simulants. Angewandte Chemie 126(2): 507511.

24. Zhao J, Lee DT, Yaga RW, Hall MG, Barton HF, et al. (2016) Ultra-Fast Degradation of Chemical Warfare Agents Using MOF-Nanofiber Kebabs. Angewandte Chemie International Edition 55(42): 13224-13228.

25. Kim MK, Kim SH, Park M, Ryu SG, Jung H (2018) Degradation of chemical warfare agents over cotton fabric functionalized with UiO-66-NH 2. RSC Advances 8(72): 41633-41638. 
ISSN: 2574-1241

DOI: $10.26717 /$ BJSTR.2020.26.004306

Ozan Yağmuroğlu. Biomed J Sci \& Tech Res

(c) (P) This work is licensed under Creative BY Commons Attribution 4.0 License

Submission Link: https://biomedres.us/submit-manuscript.php

BIOMEDICAL
RESEARCHES $\quad \begin{aligned} & \text { Assets of Publishing with us } \\ & \text { - Global archiving of articles }\end{aligned}$

